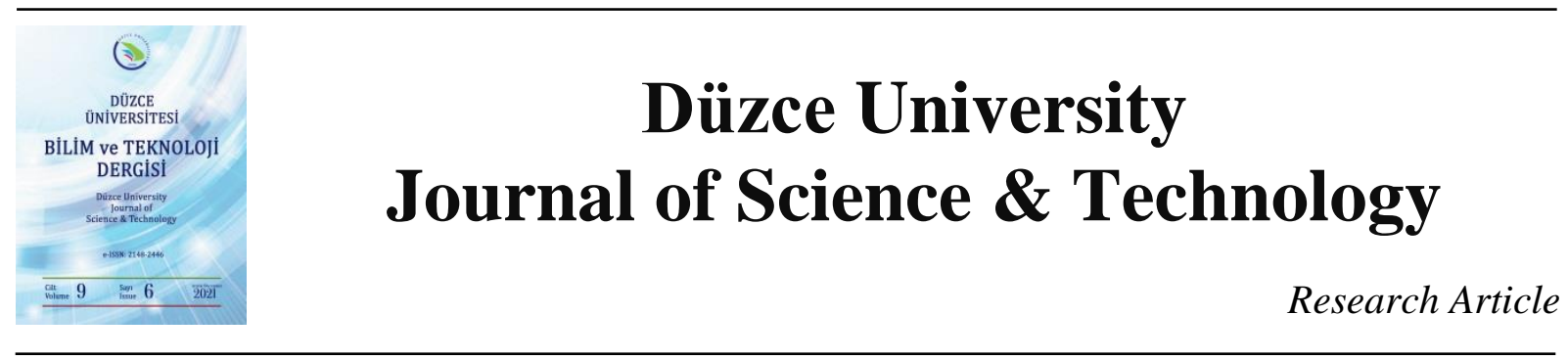

\title{
A Financial Ratio Analysis on BIST Information and Technology Index (XUTEK) Using AHP-weighted Grey Relational Analysis ${ }^{1}$
}

\author{
(iD Tunahan TURHAN ${ }^{\mathrm{a}, *}$, (DErdal AYDEMIR ${ }^{\mathrm{b}}$ \\ ${ }^{a}$ Elementary Mathematics Education, Faculty of Education, Süleyman Demirel University, Isparta, TURKEY \\ ${ }^{b}$ Dept. of Industrial Engineering, Faculty of Engineering, Süleyman Demirel University, Isparta, TURKEY \\ * Corresponding author's e-mail address: tunahanturhan@sdu.edu.tr
} DOI:10.29130/dubited.1011252

\begin{abstract}
The financial ratio analysis is an important issue for the stock exchange markets which have many sub-sectoral indexes. During Industry 4.0 revolution and transition, the sector of information and technology is shown as one of the sectors that have great strategic importance in the global change and development process. So, the performance of the information and technology sector provides a significant added value to the economies. In this study, multi-criteria decision-making (MCDM) approaches will be used to determine the weights of the criteria with considering the experts' opinions used in the evaluation of the financial performance of the companies operating in the field of Information and Technology Sector of BIST Stock Index (XUTEK). In order to measure the financial performance of companies with MCDM methods, the ratios of the liquidity, operational/activity, financial structure, and profitability are obtained from the financial statements are frequently applied in the scientific literature. In the study, criteria weights were determined by using the pairwise comparison feature of the analytical hierarchy process method and expert opinions. Then, the smallest and largest values of the financial ratio values in quarterly periods in 2020 and the uncertainty formed were evaluated with the gray relational analysis method. After all; XUTEK stocks to be included in the priority investment portfolio in terms of financial performance have been determined.
\end{abstract}

Keywords: Analytic hierarchy process, Grey relational analysis, BIST stock index, Uncertainty.

\section{AHP Ağırlıklı Gri İlişkisel Analiz Kullanarak BIST Bilişim ve Teknoloji Endeksinde (XUTEK) Finansal Oranlar Analizi}

\begin{abstract}
Öz
Finansal oran analizi, birçok alt sektör endeksine sahip borsalar için önemli bir konudur. Endüstri 4.0 devrimi ve geçiş sürecinde bilgi ve teknoloji sektörü, küresel değiş̧im ve gelişim sürecinde büyük stratejik öneme sahip sektörlerden biri olarak gösterilmektedir. Dolayısıyla bilgi ve teknoloji sektörünün performansı ekonomilere önemli bir katma değer sağlamaktadır. Bu çalışmada, Bilgi ve Teknoloji Sektörü alanında faaliyet gösteren şirketlerin finansal performanslarının değerlendirilmesinde kullanılan uzman görüşleri dikkate alınarak kriterlerin ağılıklarının belirlenmesinde çok kriterli karar verme (ÇKKV) yaklaşımları kullanılacaktır. ÇKKV yöntemleri ile şirketlerin finansal performanslarını ölçmek için finansal tablolardan elde edilen likidite, operasyonel/faaliyet, finansal yapı ve karlılık oranları bilimsel literatürde sıklıkla uygulanmaktadır. Çalışmada, analitik hiyerarşi süreç yönteminin ikili karşılaştırma özelliği ile uzman görüşleri kullanılarak kriter ağırlıkları tespit edilmiştir. Daha sonra, 2020 yılında üçer aylık dönemlerdeki finansal oran değerlerinin en küçük ve en büyük değerleri ile oluşan belirsizlik gri ilişkisel analiz yöntemi ile değerlendirilmiştir. Sonuçta; finansal performans açısından öncelikli yatıım portföyüne alınacak XUTEK hisse senetleri belirlenmiştir.
\end{abstract}

Anahtar Kelimeler: Analitik hiyerarşi süreci, Gri ilişkisel analiz, Hisse senedi endeksi, Belirsizlik.

${ }^{1}$ The part of this study was presented as an oral presentation in ICAIAME 2021, Antalya, Turkey.

Received: 18/10/2021, Revised:10/12/2021, Accepted: 13/12/2021 


\section{INTRODUCTION}

Unlike many sectors, the recent changes and developments in the information and technology sector have an extremely important place in the country's economies and as a reflection of this, in the shaping of business structures. The financial structure created by the advanced developments in the field of technology in the global economy has developed and expanded the competitive environment. With the increase in competition, businesses have had to learn to innovate, to open, to keep up with the changes in information and technology to survive and reach the cake that falls under their share in the financial environment. The information technologies provide changes in information levels. In addition, the continuous improvements in science, communication, computer, and transportation technologies play an important role in the globalization that occur in trade and economy. However, the correct determination and evaluation of business performance is important for the prediction and interpretation of situations such as the ability of businesses to compete under difficult competitive conditions, to find a place for themselves in the global market and to ensure continuity on there $[1,2]$. The information technologies businesses gain the ability to access reliable and complete information as soon as possible and to manage and market this information in the best way. Moreover, this situation enables businesses to make the right strategic decisions, reduce their costs in their activities and increase their performance. In addition, the situation of the information and technology sector, which is of great importance in the country and business economies, is thought to be directly related to the performance of the businesses operating in this field [3, 4].

Although multi-criteria decision making (MCDM) techniques have emerged to choose the best among a certain number of alternatives or to rank the alternatives, they can be used in financial performance analysis to compare the performances of the enterprises and to make forward-looking comments about the enterprises. Recently, Analytical Hierarchical Process (AHP) and Grey Relational Analysis (GRA) methods are used in most of the multi-criteria decision-making problems. It is especially seen in many sectors where financial performance analysis is performed. For example, it can be found in areas such as textile, automotive, asset management, insurance sector, portfolio management, banking [5, 6, 7, 8, $9,10]$. Then, in detail, according to near scientific literature, MCDM methods for stock selection under fuzzy environment [11, 12], AHP based stock index ranking [13], private banking stock selection with fuzzy uncertainties [14], grey based asset allocation [15], DEMATEL based portfolio selection [16], TOPSIS based stock index classification [17], financial and operational risk analysis $[18,19,20]$; stock selection on Gordon model [21]. About the studies of Borsa Istanbul (BIST) stock indexes are holding and investment index [22], PROMETHEE and TOPSIS methods for 131 manufacturing firms stock index evaluation [23], and technology index [24] like as this study used to analyze financial performance.

In this study, MCDM methods used to analyze financial performance were applied to businesses included in the BIST (Borsa Istanbul) Information and Technology Index. Thus, an idea about the financial performance of the enterprises in the sector will be formed and some data will be obtained about the enterprises. Considering the studies aiming to measure the financial performance of companies with MCDM methods, it is seen that the liquidity, activity, financial structure, and profitability ratios obtained from the financial statements are frequently used. From this point of view, a grey relational method will be applied under uncertainty by using the pairwise comparison of the Analytical Hierarchy Process (AHP) method, which helps to determine the most appropriate option by considering many independent criteria or objectives as a financial analysis application during the quarterly in year of 2020. So, the scope of this paper, which is based on these needs, is to select the Information and Technology stock indexes using AHP weighted GRA methodology with expert opinions.

The rest of this study is organized as follows: decision problem design process is given in Section 2. Then, the proposed methodology is explained by combining AHP and GRA methodologies in Section 3. The numerical study is given in Section 4 with the financial performance data. In Section 5, the conclusion and discussions are presented for considering future analysis. 


\section{MATERIALS and METHODS}

The research problem is to select and rank the stock index of information and technology sector in BIST by applying the expert's opinions and using the financial indicators during the quarterly in year of 2020. The AHP pairwise comparison matrix is used for determining the criteria weights reflecting the expert's opinions. Then, the values of financial indicators have also some changes in periods. It's explained the max and min values as an interval grey number for each financial indicator. So, for the whitenization of the values, mean and degree of greyness approaches are used to clarifying the grey uncertainties. Finally, the prioritization of the stock indexes is obtained from the classical and the proposed methodology on a convex solution.

\section{A. CRITERIA DESIGN}

Evaluating the financial performance of 18 enterprises operating in the information and technology sector with the data obtained from the balance sheets published in 2020. At first, ratio analysis method was applied to measure the financial performances of the mentioned enterprises, and then AHP and GRA methods were used. Then, Liquidity and borrowing strategies and efficiency and profitability ratios in their activities come to the fore in the financial performance evaluations of enterprises. In this context, liquidity, financial structure, profitability, and activity ratios are considered as the main criteria in the study. In addition, other sub-criteria used in the study are the most frequently used ratios in studies that reveal business performance in the literature. In the tables below, the ratios and formulas related to the main and sub-criteria are given $[25,26,27,28,29,30]$ :

Table 1. Financial evaluation criteria.

\begin{tabular}{|c|c|c|}
\hline Code & Criteria & Equation \\
\hline $\mathrm{L}$ & Liquidity Ratios & \\
\hline L1 & Current Ratio & Current Assets / Current Debts \\
\hline L2 & Quick Ratio & $\begin{array}{l}\text { (Current Assets - Inventories) / Current } \\
\text { Debts }\end{array}$ \\
\hline L3 & Cash Ratio & Liquid Assets / Current Debts \\
\hline $\mathrm{F}$ & Financial Structure Ratios & \\
\hline $\mathrm{F} 1$ & Debt Ratio & Total Debt / Total assets \\
\hline $\mathrm{F} 2$ & Total debt/Equity Ratio & Total Debt / Equity \\
\hline F3 & $\begin{array}{l}\text { Asset Coverage Ratio of Short-Term } \\
\text { Liabilities }\end{array}$ & $\begin{array}{l}\text { Ratio of Short-Term Liabilities / Total } \\
\text { Assets }\end{array}$ \\
\hline $\mathrm{O}$ & Operational/Activity Ratios & \\
\hline $\mathrm{O} 1$ & Accounts Receivable Turnover & $\begin{array}{l}\text { Net Credit Sales / Average Accounts } \\
\text { Receivable }\end{array}$ \\
\hline $\mathrm{O} 2$ & Equity Ratio & Net Sales / Equity \\
\hline $\mathrm{O} 3$ & Working Capital Ratio & $\begin{array}{l}\text { Net Sales / (Current Assets - Short- } \\
\text { term debts) }\end{array}$ \\
\hline $\mathrm{P}$ & Profitability Ratios & \\
\hline $\mathrm{P} 1$ & Net Profit Margin & Net Profit / Revenue \\
\hline $\mathrm{P} 2$ & Asset (Investment) Profitability Ratio & Net Profit / Total Assets \\
\hline P3 & Return on Equity Ratio & Net Profit / Equity \\
\hline
\end{tabular}




\section{B. METHODS}

\section{B. 1. Analytical Hierarchy Process (AHP)}

The Analytical Hierarchy Process (AHP), developed by Saaty (1977), is a method that hierarchically identifies the problem addressed through objectives, criteria, sub-criteria and options to find solutions to complex decision-making problems. It represents an accurate approach to quantifying the weights of decision criteria. Individual experts' experiences are utilized to estimate the relative magnitudes of factors through pair-wise comparisons. Each of the respondents compares the relative importance each pair of items using a specially designed questionnaire. With the help of this hierarchical structure, decision options are subjected to scoring and ranking by using many performance criteria, thus simplifying the decision-making process. By making pairwise comparisons in complex decision problems with AHP, it is evaluated to what extent the options and criteria are dominant according to their relative importance. The AHP consists of four steps [31, 32]:

- Identify the decision, options, and criteria.

- Conduct pairwise comparisons.

- Calculate the importance weight of each criterion.

- Identify the best option by calculating something called utility.

Step 1: Comparison matrix is created in which pairwise comparisons will be made. While making the comparison, the scale is used 1 to 9 from Saaty [33].

Step 2: The generated comparison matrix is standardized. For this, column totals are taken, and each value is divided by its column total. Thus, the standardized matrix is obtained.

Step 3: The row average is taken to obtain the weights.

Step 4: After the weights are obtained, the consistency of the comparison matrix should be checked. If the comparison matrix is not consistent, the resulting weights cannot be used.

$A \cdot w=\lambda_{\max } \cdot w$

The max vector satisfying the equality must be obtained first. Here, $\mathrm{A}$ is the comparison matrix and $\mathrm{w}$ is also the resulting weight matrix. Calculations are made using max in equation 2 and the "consistency index (CI)", which is considered as an indicator of closeness to consistency, is obtained.

$C I=\frac{\lambda_{\max }-n}{n-1}$

After the CI value is calculated, another value that needs to be obtained is the "Randomness Index (RI)". This value is tabulated for different matrix sizes. The RI values for different matrix sizes are shown in Table 2 [33].

Table 2. Randomness index.

\begin{tabular}{cccccccccccccccc}
\hline $\boldsymbol{n}$ & $\boldsymbol{1}$ & $\mathbf{2}$ & $\mathbf{3}$ & $\mathbf{4}$ & $\mathbf{5}$ & $\mathbf{6}$ & $\mathbf{7}$ & $\mathbf{8}$ & $\mathbf{9}$ & $\mathbf{1 0}$ & $\mathbf{1 1}$ & $\mathbf{1 2}$ & $\mathbf{1 3}$ & $\mathbf{1 4}$ & $\mathbf{1 5}$ \\
\hline $\boldsymbol{R I}$ & 0.00 & 0.00 & 0.58 & 0.90 & 1.12 & 1.24 & 1.32 & 1.41 & 1.45 & 1.49 & 1.51 & 1.48 & 1.56 & 1.57 & 1.59 \\
\hline
\end{tabular}


AHP method is a frequently preferred method for solving multi-criteria decision problems. When the scientific literature is examined, supplier selection is mostly preferred in problem types $[34,35,36$, 37]. Like this study, AHP was applied for stock index ranking [13]. In this study, the pairwise comparison of AHP method applied for determining the criteria and sub-criteria weights. So, the pairwise comparison approach is reliable in decreasing the effect of subjective point-of-views associated with eliciting the weights directly [38].

\section{B. 2. Grey Relational Analysis (GRA)}

Grey Relational Analysis (GRA) is a multi-criteria decision-making method for selecting, ranking, and classifying the decision-making problems which have incomplete and inadequate knowledge situations. The qualitive and quantitative measures between two decision sequences are called grey relational degrees and are assigned values between 0 and 1. GRA is a useful method that can be applied to decision problems where the relationships between factors have higher complexity. Therefore, it can be used as a unique and/or hybrid model to solve many types of multi-criteria decision problems. The advantages of the method are that a small data set is sufficient for the application, calculation process is simple, and a specific package program is not required in real world problems. The primary procedure of GRA is to convert the performance of all alternatives into a benchmarking sequence at the beginning [39, 40, 41, 42, 43]. The six steps of the GRA are given below $[44,45]$ :

\section{Step 1: Creating the Decision Matrix}

A decision matrix is created showing the values of the alternatives for each criterion, a decision matrix consisting of $n$ alternatives, m criteria,

$$
X_{i}(j)=\left[\begin{array}{cccc}
x_{1}(1) & x_{1}(2) & \ldots & x_{1}(m) \\
x_{2}(1) & x_{2}(2) & \ldots & x_{2}(m) \\
\vdots & \vdots & \ddots & \vdots \\
x_{n}(1) & x_{n}(2) & \ldots & x_{n}(m)
\end{array}\right] i=1, \ldots, n, j=1, \ldots, m
$$

Here $X_{i}(j)$ indicates the value of $i$. alternative for $\mathrm{j}$. criterion.

Step 2: Standardization process: Since the criteria are measured in different units, standardization is done to make them comparable with each other. In the standardization process, three different equations are used according to the preference of high, low or ideal value,

$x_{i}^{\prime}(j)=\frac{x_{i}(j)-\min _{i=1}^{n} x_{i}(j)}{\max _{i=1}^{n} x_{i}(j)-\min _{i=1}^{n} x_{i}(j)}$, if bigger value is better,

$x_{i}^{\prime}(j)=\frac{\max _{i=1}^{n} x_{i}(j)-x_{i}(j)}{\max _{i=1}^{n} x_{i}(j)-\min _{i=1}^{n} x_{i}(j)}$, if smaller value is better,

$x_{i}^{\prime}(j)$

$=1-\frac{\left|x_{i}(j)-x_{i d l}(j)\right|}{\max \left\{\max _{i=1}^{n} x_{i}(j)-x_{i d l}(j), x_{i d l}(j)-\min _{i=1}^{n} x_{i}(j)\right\}}$, if the ideal value is better.

Here $x_{i d l}(j)$ represents the ideal value, large values are optimized for all cases after standardization is applied, and standardized values take values between 0 and 1 .

Step 3: Creating the standardized decision matrix and reference series: At this stage, a standardized decision matrix is created by using the values obtained in the previous step. The reference series is created from the largest values in each column of the standardized decision matrix. 
Step 4: Creating the difference matrix: The difference matrix is obtained by subtracting the reference series from the standardized decision matrix.

$\Delta_{0 i}(j)=\left|x_{0}^{\prime}(j)-x_{i}^{\prime}(j)\right|$,

$\Delta_{i j}=\left[\begin{array}{cccc}\Delta_{01}(1) & \Delta_{01}(2) & \ldots & \Delta_{01}(m) \\ \Delta_{02}(1) & \Delta_{02}(2) & \ldots & \Delta_{02}(m) \\ \vdots & \vdots & \ddots & \vdots \\ \Delta_{0 n}(1) & \Delta_{0 n}(2) & \ldots & \Delta_{0 n}(m)\end{array}\right]$

Step 5: Calculation of grey relational coefficients: For each value in the difference matrix, the grey relational coefficient is calculated as

$$
\gamma_{0 i}(j)=\frac{\min _{i=1}^{n} \min _{j=1}^{m} \Delta_{0 i}(j)+\xi \times \max _{i=1}^{n} \max _{j=1}^{m} \Delta_{0 i}(j)}{\Delta_{0 i}(j)+\xi \times \max _{i=1}^{n} \max _{j=1}^{m} \Delta_{0 i}(j)} .
$$

Here, $\zeta$ is a coefficient that takes a value between 0 and 1 and is usually taken as 0.5 .

Step 6: Calculating the grey relationship degree: When the obtained grey relational coefficients are multiplied by the weight of the relevant criterion and summed for each alternative, the grey relation degree is obtained. When the values of the grey relationship degree for each alternative are ordered from the largest to the smallest, the alternatives are ranked from the best to the worst.

\section{B.3. Proposed Methodology}

In this study, after determining the financial criteria, stocks of BIST information and technology index and experts, the pairwise comparison of AHP is used to obtain the criteria weights by applying the expert opinions. Then, the criteria values are gathered for 18 stocks in quarterly of 2020 . After that, the minimum and maximum criteria values are assigned from the financial data during year of 2020 as an interval grey number. Then, the whitenization of the interval grey criteria values is applied with mean and degree of greyness approaches. On the other hand, using the degree of greyness was used firstly for whitenization methods of the interval grey number by Aydemir et al. in 2015 [46].

Finally, GRA is also applied in twice for the whitenization approaches. As a results, the rankings are listed by using two models and convex solution. The experts' qualification levels are given as Figure 1 and the proposed methodology is given as Figure 2.

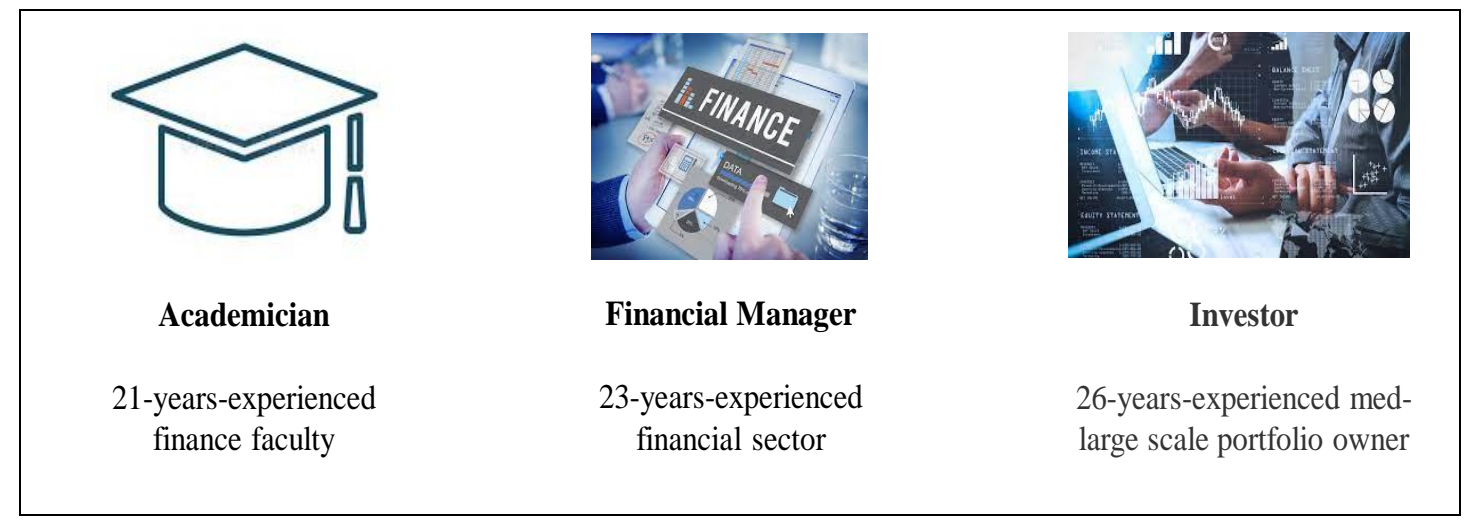

Figure 1. The experts' qualification levels. 
The pairwise comparison matrices are evaluated, and the consistency ratios of the main and subcriteria are calculated for all experts. In the calculations, it is seen that the consistency ratios are less than 0.10 . Since the main and sub-criteria were compared by more than one expert in the study, they were evaluated with the coefficients determined that Investor is to be 1 , Academician is to be 2 and Financial Manager is to be 3 in 6 value of total weight and expert evaluations were combined with the weighted average method. So, the expert opinions were not evaluated equally in this study.

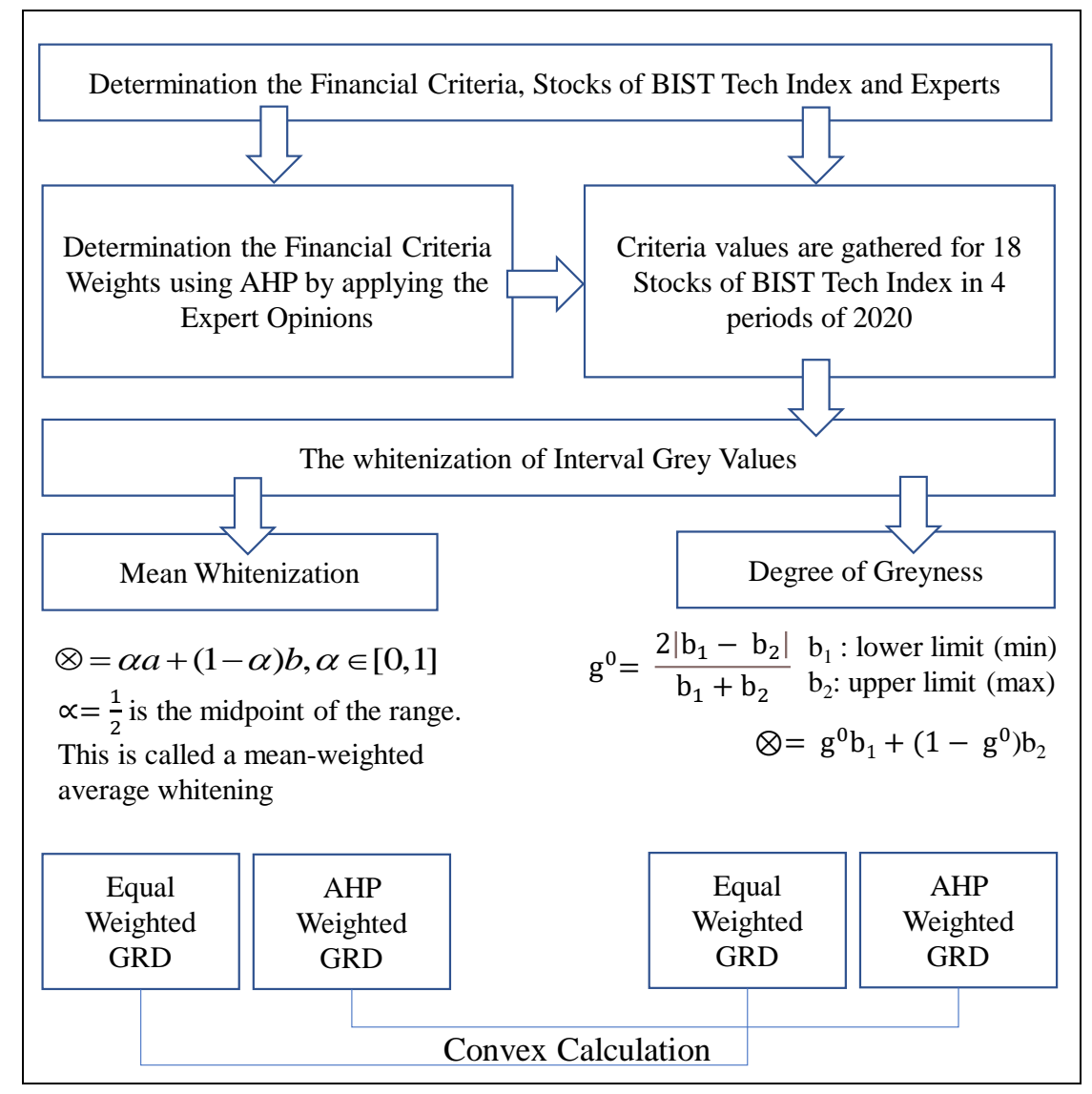

Figure 2. The proposed methodology.

\section{THE CASE ANALYSIS}

The aim of this study is to evaluate the performances of 18 companies operating in the field of information and technology registered in BIST with the data obtained from 2020 and to rank the companies from the best to the worst according to their performance. The hierarchical tree diagram used in the study is given in Figure 3. 


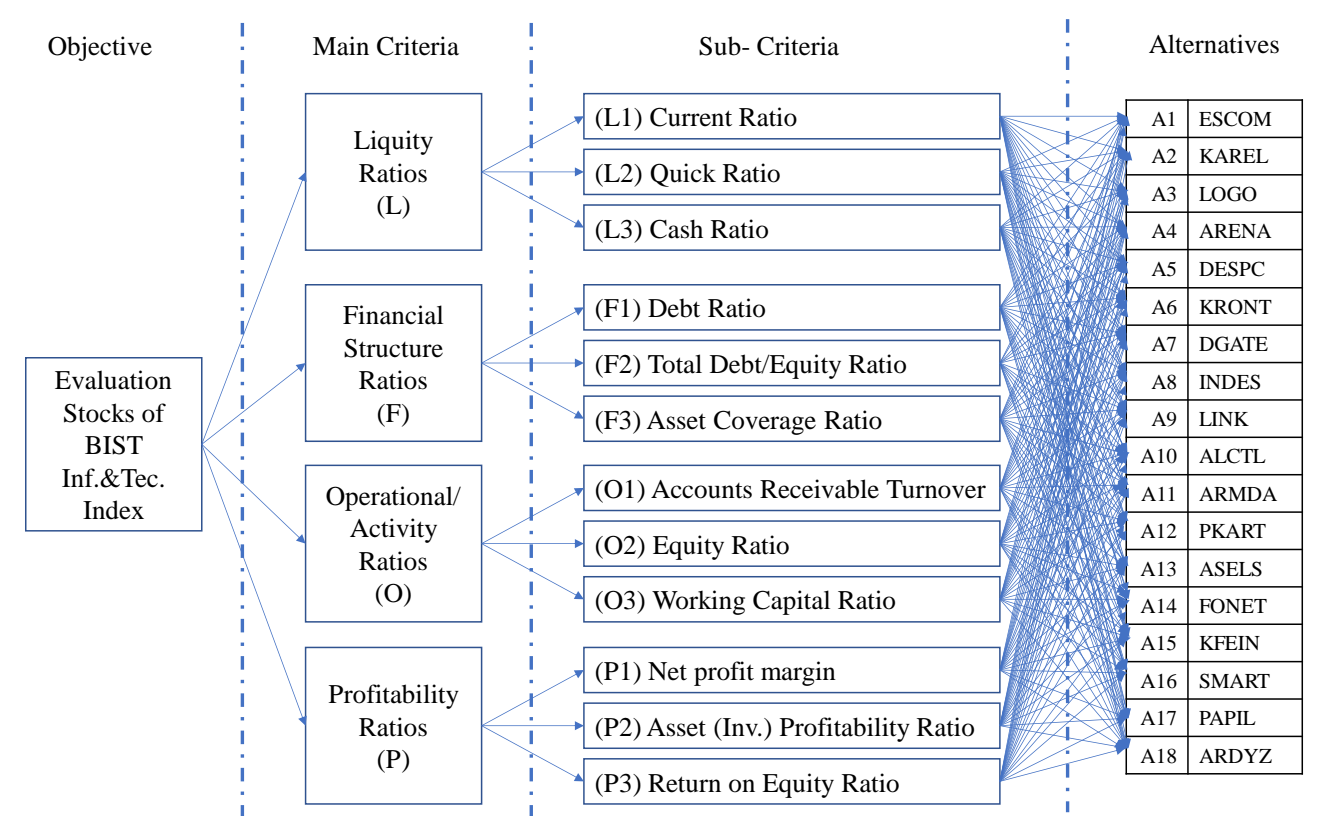

Figure 3. The hierarchical decision scheme of study.

While making the application, the criteria weights were found with the help of AHP pairwise comparison approach based on the expert opinions. Three experts in the field, whose information is given above, compared the main and sub-criteria in pairs with the help of a questionnaire to obtain the criterion weights. In these comparisons, the scale developed by Saaty 1-9 scale. The final criteria weights are given as Table 3 .

Table 3. Criteria weights by applying the experts' opinions.

\begin{tabular}{llcc}
\hline Main Criteria & Sub-Criteria & $\begin{array}{c}\text { Sub-Criteria } \\
\text { Weights }\end{array}$ & $\begin{array}{c}\text { Main-Criteria } \\
\text { Weights }\end{array}$ \\
\hline \multirow{2}{*}{ Liquidity Ratios (L) } & L1: Current Rate & 0.025 & \\
& L2: Quick Ratio & 0.046 & 0.174 \\
\hline \multirow{2}{*}{ Financial Structure } & L3: Cash Ratio & 0.103 & \multirow{2}{*}{0.127} \\
Ratios (F) & F1: Debt Ratio & 0.026 & \\
\hline \multirow{2}{*}{ Activity Ratios (O) } & F3: Asset Coverage Ratio of Short-Term Liabilities & 0.082 & 0.019 \\
& O1: Accounts Receivable Turnover & 0.034 & \multirow{2}{*}{0.120} \\
& O2: Equity Ratio & 0.016 & 0.579 \\
\hline \multirow{2}{*}{ Profitability Ratios (P) } & O3: Working Capital Ratio & 0.070 & 0.363 \\
& P1: Net profit margin & 0.062 & \\
\hline
\end{tabular}

According to Table 3, the main criterion with the highest weight is the profitability ratio with $57.9 \%$, the liquidity ratio at the second place with $17.4 \%$, the financial structure ratio at the third place with $12.7 \%$ and the activity ratio with $12.0 \%$ takes fourth place.

Then, the performances of businesses may differ from year to year and even from period to period. For this reason, the limits for the general outlook of the sector were determined by using the maximum and minimum values of the ratios obtained from the financial data of the enterprises discussed in the study for each balance sheet period of 2020. In this study, there are 18 alternatives (stocks), 12 sub-criteria of 4 main criteria. Table 4 shows the min and max financial data obtained from quarterly of the year 2020 . 
Then, the whitenization of the interval grey criteria values is applied with mean and degree of greyness approaches. After this for each model, the normalization process is applied separately. As it is known, the rates discussed in the study may differ according to the sector in which the enterprises are located, the size of the enterprise, their sales and the financing policy applied by the enterprises. Therefore, while giving ideal values in the study, values close to the generally accepted ratios in the scientific literature are considered. In this context, maximum values for Liquidity, Profitability and Activity ratios and accepted ideal values for Financial Structure Ratios are used. Equation 4 is used when normalization for the Liquidity, Profitability and Activity ratios, and equation 6 is used when normalization for the Financial Structure Ratios. Then, the Reference Series (A0) is created from the largest values of each column. The normalized decision matrix and reference values are given for mean weighted and degree of greyness approaches in the Table 5 and Table 6 respectively.

The rest steps of GRA are applied for each model and grey relational degrees are obtained for each model separately. In addition, to show effects of the AHP pairwise comparison weighted models, all models are solved with the classical GRA which has applied using the equal weights of the criteria. On the other hand, the expert opinions have not affected the results on the classical GRA. Furthermore, mean weighted and degree of greyness whitenization approaches are evaluated by classical and AHPweighted GRA models together. Finally, all results are given in Table 7. 
Table 4. Applying the GRA for Min-Max Interval Values from the four periods in 2020.

\begin{tabular}{|c|c|c|c|c|c|c|c|c|c|c|c|c|}
\hline & \multicolumn{3}{|c|}{ Liquidity Ratios } & \multicolumn{3}{|c|}{ Financial Structure } & \multicolumn{3}{|c|}{ Activity Ratios } & \multicolumn{3}{|c|}{ Profitability Ratios } \\
\hline $\mathrm{w}$ & \multicolumn{3}{|c|}{0.174} & \multicolumn{3}{|c|}{0.127} & \multicolumn{3}{|c|}{0.12} & \multicolumn{3}{|c|}{0.579} \\
\hline w & 0.025 & 0.046 & 0.103 & 0.026 & 0.082 & 0.019 & 0.034 & 0.016 & 0.07 & 0.363 & 0.062 & 0.154 \\
\hline \multirow[t]{3}{*}{ Obj } & $\max$ & $\max$ & $\max$ & 0.5 & 0.5 & 0.3 & $\max$ & $\max$ & $\max$ & $\max$ & $\max$ & $\max$ \\
\hline & L1 & $\mathrm{L} 2$ & L3 & F1 & F2 & F3 & 01 & 02 & 03 & P1 & P2 & P3 \\
\hline & \begin{tabular}{l|l} 
Min & Max
\end{tabular} & Max & \begin{tabular}{l|l} 
Min & Max
\end{tabular} & 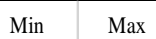 & \begin{tabular}{l|l} 
Min & Max \\
\end{tabular} & \begin{tabular}{l|l} 
Min & Max
\end{tabular} & Max & \begin{tabular}{|l|l|} 
Min & Max \\
\end{tabular} & 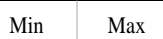 & Max & \begin{tabular}{l|l} 
Min & Max
\end{tabular} & \begin{tabular}{l|l} 
Min & Max
\end{tabular} \\
\hline
\end{tabular}

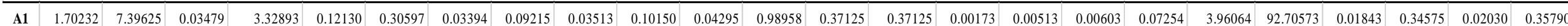

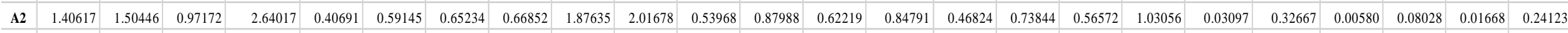

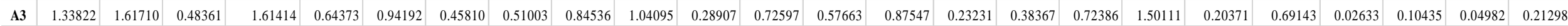

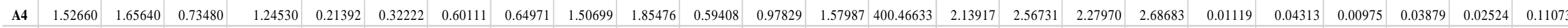

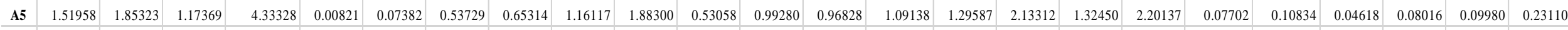

\begin{tabular}{|l|l|l|l|l|l|l|l|l|l|l|l|l|l|l|l|l|l|l|l|l|l|l|l|l|l|l} 
A6 & 1.44869 & 1.64778 & 0.15400 & 1.51023 & 0.37892 & 0.53901 & 0.37712 & 0.41506 & 0.60545 & 0.70956 & 0.34096 & 0.93522 & 0.19408 & 2.05094 & 0.13984 & 0.18032 & 0.39710 & 0.62256 & 0.11447 & 1.27246 & 0.01286 & 0.10409 & 0.02064 & 0.17794 \\
\hline
\end{tabular}

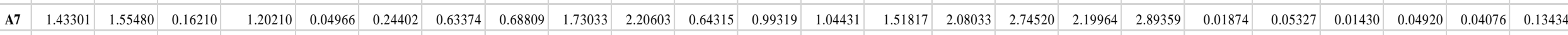

\begin{tabular}{l|l|l|l|l|l|l|l|l|l|l|l|l|l|l|l|l|l|l|l|l|l|l|l|l|l|l} 
A8 & 1.16355 & 1.20696 & 0.98208 & 1249.63056 & 0.19913 & 0.39082 & 0.79466 & 0.83579 & 3.86985 & 5.08965 & 0.78693 & 0.99423 & 1.06137 & 1.59164 & 3.57111 & 4.80623 & 4.50260 & 5.89265 & 0.01310 & 0.04472 & 0.00961 & 0.03529 & 0.04679 & 0.21493 \\
\hline
\end{tabular}

\begin{tabular}{l|l|l|l|l|l|l|l|l|l|l|l|l|l|l|l|l|l|l|l|l|l|l|l|l|l|l|l|l|l|l} 
A9 & 12.62936 & 18.56755 & 0.09744 & 16.00031 & 10.68998 & 16.68194 & 0.10229 & 0.11453 & 0.11395 & 0.12935 & 0.04128 & 0.53745 & 1.02266 & 1.39550 & 0.08427 & 0.18601 & 0.10204 & 0.23008 & 0.62166 & 2.24024 & 0.04739 & 0.23547 & 0.05278 & 0.26593 \\
\hline
\end{tabular}

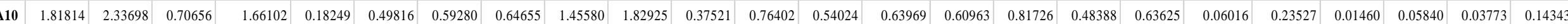

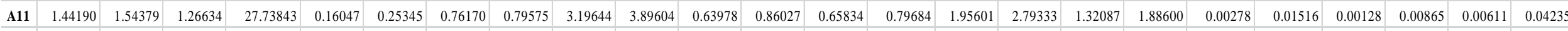

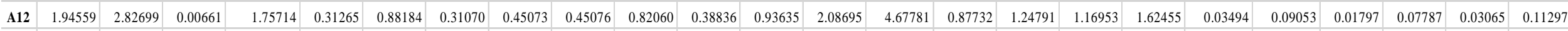

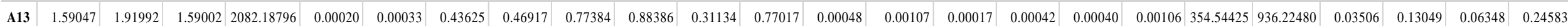

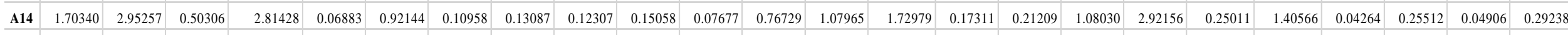

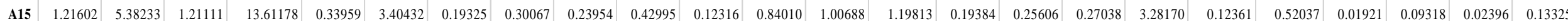

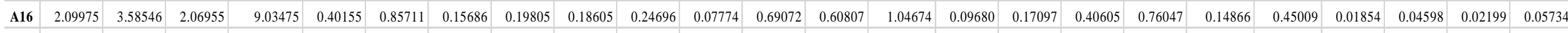

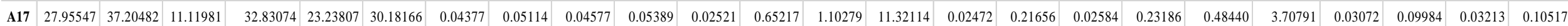

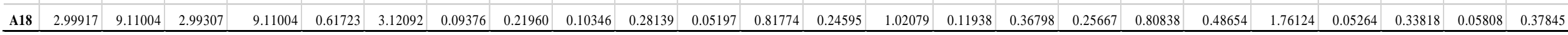


Table 5. Normalized decision matrix for mean weighted whitenization of GRA.

\begin{tabular}{|c|c|c|c|c|c|c|c|c|c|c|c|c|}
\hline & \multicolumn{3}{|c|}{ Liquidity Ratios } & \multicolumn{3}{|c|}{ Financial Structure } & \multicolumn{3}{|c|}{ Profitability Ratios } & \multicolumn{3}{|c|}{ Activity Ratios } \\
\hline $\mathbf{w}$ & 0.025 & 0.046 & 0.103 & 0.026 & 0.082 & 0.019 & 0.363 & 0.062 & 0.154 & 0.034 & 0.016 & 0.070 \\
\hline Obj & $\max$ & $\max$ & $\max$ & 0.5 & 0.5 & 0.3 & $\max$ & $\max$ & $\max$ & $\max$ & $\max$ & $\max$ \\
\hline & L1 & L2 & $\mathbf{L 3}$ & F1 & F2 & F3 & $\begin{array}{ll}\text { P1 } \\
\end{array}$ & $\mathbf{P 2}$ & P3 & 01 & 02 & $\mathbf{0 3}$ \\
\hline A0 & 1.00000 & 1.00000 & 1.00000 & 1.00000 & 1.00000 & 1.00000 & 1.00000 & 1.00000 & 1.00000 & 1.00000 & 1.00000 & 1.00000 \\
\hline A1 & 0.10715 & 0.00096 & 0.00799 & 0.96555 & 0.10847 & 0.36619 & 0.07488 & 0.93006 & 0.84968 & 0.00184 & 0.00075 & 0.00742 \\
\hline A2 & 0.00860 & 0.00108 & 0.01868 & 0.35450 & 0.36348 & 0.69387 & 0.00026 & 0.19992 & 0.53971 & 0.00365 & 0.14398 & 0.15344 \\
\hline A3 & 0.00931 & 0.00035 & 0.02967 & 0.03521 & 0.11135 & 0.35138 & 0.00068 & 0.31704 & 0.55231 & 0.00361 & 0.07346 & 0.21393 \\
\hline A4 & 0.01294 & 0.00030 & 0.01003 & 0.27712 & 0.29672 & 0.82323 & 0.00003 & 0.10137 & 0.22551 & 1.00000 & 0.56178 & 0.47770 \\
\hline A5 & 0.01596 & 0.00199 & 0.00153 & 0.21039 & 0.25682 & 0.78176 & 0.00013 & 0.30563 & 0.72780 & 0.00512 & 0.40928 & 0.33909 \\
\hline A6 & 0.01156 & 0.00014 & 0.01717 & 0.22961 & 0.03958 & 0.57248 & 0.00106 & 0.28096 & 0.38684 & 0.00558 & 0.03815 & 0.09796 \\
\hline A7 & 0.00983 & 0.00000 & 0.00549 & 0.35558 & 0.36891 & 0.87739 & 0.00004 & 0.14067 & 0.32631 & 0.00637 & 0.57599 & 0.48989 \\
\hline A8 & 0.00000 & 0.59990 & 0.01103 & 0.69655 & 1.00000 & 1.00000 & 0.00003 & 0.09183 & 0.54956 & 0.00659 & 1.00000 & 1.00000 \\
\hline A9 & 0.45909 & 0.00708 & 0.51239 & 0.86530 & 0.09507 & 0.01801 & 0.00220 & 0.71655 & 0.69640 & 0.00601 & 0.03219 & 0.03181 \\
\hline A10 & 0.02842 & 0.00048 & 0.01273 & 0.26445 & 0.28709 & 0.45653 & 0.00021 & 0.16561 & 0.34194 & 0.00293 & 0.17027 & 0.10763 \\
\hline A11 & 0.00980 & 0.01327 & 0.00774 & 0.61591 & 0.76543 & 0.76201 & 0.00000 & 0.00000 & 0.00000 & 0.00362 & 0.56690 & 0.30840 \\
\hline A12 & 0.03826 & 0.00019 & 0.02235 & 0.26358 & 0.03409 & 0.61356 & 0.00008 & 0.22556 & 0.24522 & 0.01682 & 0.25363 & 0.26868 \\
\hline A13 & 0.01815 & 1.00000 & 0.00000 & 0.10449 & 0.08263 & 0.40766 & 1.00000 & 0.40859 & 0.67218 & 0.00000 & 0.00000 & 0.00000 \\
\hline A14 & 0.03640 & 0.00094 & 0.01853 & 0.83919 & 0.09126 & 0.20663 & 0.00127 & 0.75567 & 0.75497 & 0.00698 & 0.04591 & 0.38488 \\
\hline A15 & 0.06733 & 0.00646 & 0.07008 & 0.55914 & 0.04152 & 0.30755 & 0.00049 & 0.26902 & 0.28022 & 0.00548 & 0.05364 & 0.34161 \\
\hline A16 & 0.05279 & 0.00468 & 0.02355 & 0.71273 & 0.07123 & 0.14263 & 0.00045 & 0.14335 & 0.07956 & 0.00411 & 0.03189 & 0.11209 \\
\hline A17 & 1.00000 & 0.02045 & 1.00000 & 1.00000 & 0.11311 & 0.06552 & 0.00323 & 0.31671 & 0.22895 & 0.03090 & 0.02873 & 0.02465 \\
\hline A18 & 0.15510 & 0.00516 & 0.06997 & 0.75865 & 0.07729 & 0.22835 & 0.00173 & 1.00000 & 1.00000 & 0.00315 & 0.05811 & 0.10233 \\
\hline
\end{tabular}

Table 6. Normalized decision matrix for degree of greyness whitenization of GRA.

\begin{tabular}{|c|c|c|c|c|c|c|c|c|c|c|c|c|}
\hline & \multicolumn{3}{|c|}{ Liquidity Ratios } & \multicolumn{3}{|c|}{ Financial Structure } & \multicolumn{3}{|c|}{ Profitability Ratios } & \multicolumn{3}{|c|}{ Activity Ratios } \\
\hline $\mathbf{w}$ & 0.025 & 0.046 & 0.103 & 0.026 & 0.082 & 0.019 & 0.363 & 0.062 & 0.154 & 0.034 & 0.016 & 0.070 \\
\hline Obj & $\max$ & $\max$ & $\max$ & 0.5 & 0.5 & 0.3 & $\max$ & $\max$ & $\max$ & $\max$ & $\max$ & $\max$ \\
\hline & L1 & L2 & $\mathbf{L 3}$ & F1 & F2 & $\mathbf{F 3}$ & P1 & $\mathbf{P 2}$ & P3 & 01 & $\mathbf{0 2}$ & $\mathbf{0 3}$ \\
\hline A0 & 1.00000 & 1.00000 & 1.00000 & 1.00000 & 1.00000 & 1.00000 & 1.00000 & 1.00000 & 1.00000 & 1.00000 & 1.00000 & 1.00000 \\
\hline A1 & 0.99085 & 0.97413 & 0.41344 & 0.89035 & 1.00000 & 0.98872 & 1.00000 & 1.00000 & 1.00000 & 0.00000 & 0.57301 & 0.99844 \\
\hline A2 & 0.02520 & 0.27559 & 0.07505 & 1.00000 & 0.90735 & 0.11559 & 0.87815 & 0.94676 & 0.95564 & 0.15476 & 0.18883 & 0.27322 \\
\hline A3 & 0.12404 & 0.37954 & 0.07944 & 0.82591 & 0.62056 & 0.36158 & 0.50177 & 0.52083 & 0.45186 & 0.20743 & 0.21978 & 0.34913 \\
\hline A4 & 0.03664 & 0.00000 & 0.09853 & 0.88813 & 0.62157 & 0.12165 & 0.55933 & 0.52300 & 0.46778 & 1.00000 & 0.00000 & 0.00000 \\
\hline A5 & 0.13148 & 0.42655 & 0.91629 & 0.64220 & 0.05464 & 0.19781 & 0.00000 & 0.00000 & 0.00000 & 0.06024 & 0.21758 & 0.21771 \\
\hline A6 & 0.07500 & 0.75218 & 0.06077 & 0.85013 & 0.72454 & 0.40700 & 0.88903 & 0.81158 & 0.79726 & 0.83365 & 0.05038 & 0.18170 \\
\hline A7 & 0.03661 & 0.68121 & 0.72751 & 0.87861 & 0.54777 & 0.08241 & 0.41461 & 0.44543 & 0.27763 & 0.18639 & 0.06649 & 0.07088 \\
\hline A8 & 0.00000 & 0.99994 & 0.26669 & 0.94542 & 0.48289 & 0.04334 & 0.50434 & 0.48119 & 0.49537 & 0.20146 & 0.08020 & 0.06757 \\
\hline A9 & 0.28059 & 0.98572 & 0.12165 & 0.81404 & 0.79183 & 0.91203 & 0.52942 & 0.62874 & 0.54850 & 0.15541 & 0.40544 & 0.39638 \\
\hline A10 & 0.17379 & 0.19621 & 0.45664 & 0.86912 & 0.57817 & 0.24665 & 0.56567 & 0.52551 & 0.37649 & 0.08495 & 0.07746 & 0.07058 \\
\hline A11 & 0.02579 & 0.88417 & 0.12950 & 0.95957 & 0.64197 & 0.00389 & 0.69534 & 0.75220 & 0.70789 & 0.09593 & 0.12119 & 0.12308 \\
\hline A12 & 0.27135 & 0.99194 & 0.47405 & 0.27804 & 0.17349 & 0.33996 & 0.36583 & 0.56522 & 0.35562 & 0.38603 & 0.11846 & 0.10562 \\
\hline A13 & 0.12320 & 1.00000 & 0.17309 & 0.89858 & 0.77883 & 0.35361 & 0.37601 & 0.48820 & 0.38871 & 0.38260 & 0.46266 & 0.47780 \\
\hline A14 & 0.40773 & 0.59257 & 1.00000 & 0.67906 & 0.63387 & 0.86142 & 0.70608 & 0.70596 & 0.63696 & 0.23325 & 0.01450 & 0.49378 \\
\hline A15 & 1.00000 & 0.78143 & 0.94200 & 0.13671 & 0.14596 & 0.76627 & 0.59689 & 0.61794 & 0.60175 & 0.08742 & 0.06723 & 1.00000 \\
\hline A16 & 0.39637 & 0.49879 & 0.31731 & 0.56340 & 0.46366 & 0.83510 & 0.44648 & 0.24813 & 0.09831 & 0.26719 & 0.26419 & 0.28970 \\
\hline A17 & 0.20165 & 0.31886 & 0.00000 & 0.72512 & 0.71489 & 1.00000 & 0.80089 & 0.41359 & 0.27258 & 0.82899 & 1.00000 & 0.93689 \\
\hline A18 & 0.79323 & 0.33428 & 0.73841 & 0.63757 & 0.90059 & 0.94188 & 0.53146 & 0.73302 & 0.67984 & 0.61653 & 0.59526 & 0.56940 \\
\hline
\end{tabular}

Table 7. All results.

\begin{tabular}{|c|c|c|c|c|c|c|c|c|c|c|c|c|}
\hline & \multicolumn{4}{|c|}{ Mean Whitenization } & \multicolumn{4}{|c|}{ Degree of Greyness } & \multicolumn{4}{|c|}{ Convex Decision } \\
\hline & \multicolumn{2}{|c|}{ Classical GRA } & \multicolumn{2}{|c|}{ AHP_weighted GRA } & \multicolumn{2}{|c|}{ Classical GRA } & \multicolumn{2}{|c|}{ AHP_weighted GRA } & \multicolumn{2}{|c|}{ Classical GRA } & \multicolumn{2}{|c|}{ AHP_weighted GRA } \\
\hline & GRD & Rank & GRD & Rank & GRD & Rank & GRD & Rank & GRD & Rank & GRD & Rank \\
\hline A1 & 0.48023 & 5 & 0.46129 & 4 & 0.83839 & 1 & 0.90633 & 1 & 0.65931 & 1 & 0.68381 & 1 \\
\hline A2 & 0.40132 & 12 & 0.38600 & 10 & 0.59084 & 5 & 0.70207 & 2 & 0.49608 & 9 & 0.54404 & 3 \\
\hline A3 & 0.37523 & 17 & 0.37811 & 13 & 0.46762 & 15 & 0.47687 & 14 & 0.42143 & 16 & 0.42749 & 14 \\
\hline A4 & 0.47280 & 6 & 0.39739 & 9 & 0.49794 & 12 & 0.49737 & 12 & 0.48537 & 10 & 0.44738 & 12 \\
\hline A5 & 0.42612 & 11 & 0.40997 & 8 & 0.42730 & 18 & 0.40795 & 18 & 0.42671 & 15 & 0.40896 & 17 \\
\hline A6 & 0.37564 & 16 & 0.36451 & 16 & 0.58077 & 7 & 0.66613 & 3 & 0.47820 & 12 & 0.51532 & 7 \\
\hline A7 & 0.43196 & 10 & 0.38515 & 11 & 0.47543 & 13 & 0.47660 & 15 & 0.45369 & 13 & 0.43087 & 13 \\
\hline A8 & 0.61635 & 1 & 0.50707 & 2 & 0.50433 & 11 & 0.49888 & 11 & 0.56034 & 3 & 0.50298 & 8 \\
\hline A9 & 0.45106 & 7 & 0.43287 & 6 & 0.57722 & 8 & 0.54052 & 9 & 0.51414 & 7 & 0.48669 & 10 \\
\hline A10 & 0.37620 & 15 & 0.36514 & 15 & 0.46012 & 17 & 0.48582 & 13 & 0.41816 & 18 & 0.42548 & 15 \\
\hline A11 & 0.43502 & 9 & 0.38407 & 12 & 0.53009 & 10 & 0.56915 & 8 & 0.48256 & 11 & 0.47661 & 11 \\
\hline A12 & 0.38265 & 13 & 0.36094 & 17 & 0.47313 & 14 & 0.46201 & 16 & 0.42789 & 14 & 0.41147 & 16 \\
\hline A13 & 0.49181 & 3 & 0.66013 & 1 & 0.54236 & 9 & 0.49922 & 10 & 0.51708 & 5 & 0.57967 & 2 \\
\hline A14 & 0.44287 & 8 & 0.42915 & 7 & 0.58709 & 6 & 0.62830 & 4 & 0.51498 & 6 & 0.52872 & 6 \\
\hline A15 & 0.38237 & 14 & 0.36650 & 14 & 0.61579 & 4 & 0.61152 & 5 & 0.49908 & 8 & 0.48901 & 9 \\
\hline A16 & 0.37175 & 18 & 0.35123 & 18 & 0.46646 & 16 & 0.44673 & 17 & 0.41911 & 17 & 0.39898 & 18 \\
\hline A17 & 0.51801 & 2 & 0.45450 & 5 & 0.63664 & 2 & 0.60581 & 6 & 0.57733 & 2 & 0.53015 & 5 \\
\hline A18 & 0.48727 & 4 & 0.49360 & 3 & 0.62803 & 3 & 0.59293 & 7 & 0.55765 & 4 & 0.54327 & 4 \\
\hline
\end{tabular}

About the ranking the financial performances, using the mean weighted whitenization approach for clarifying the greyness, A8 - A17 - A13 - A18 - A1 ranking order of the first five is obtained from the classical GRA, and then, A13 - A8 - A18 - A1 - A17 ranking order of the first five is obtained from the AHP-weighted (experts' opinions) GRA. On the other hand, using the degree of greyness approach for clarifying the greyness, A1 - A17 - A18 - A15 - A2 ranking order of the first five is 
obtained from the classical GRA, and then, A1 - A2 - A6 - A14 - A15 ranking order of the first five is obtained from the AHP-weighted GRA. In addition, a convex decision which is obtained the average of the mean weighted and degree of greyness approaches, A1 - A17 - A8 - A18 - A13 ranking order of the first five is obtained from the classical GRA, and then, A1 - A13 - A2 - A18 A17 ranking order of the first five is obtained from the AHP-weighted GRA. The changes of GRD results for the models are given as Figure 4 with using radar chart.
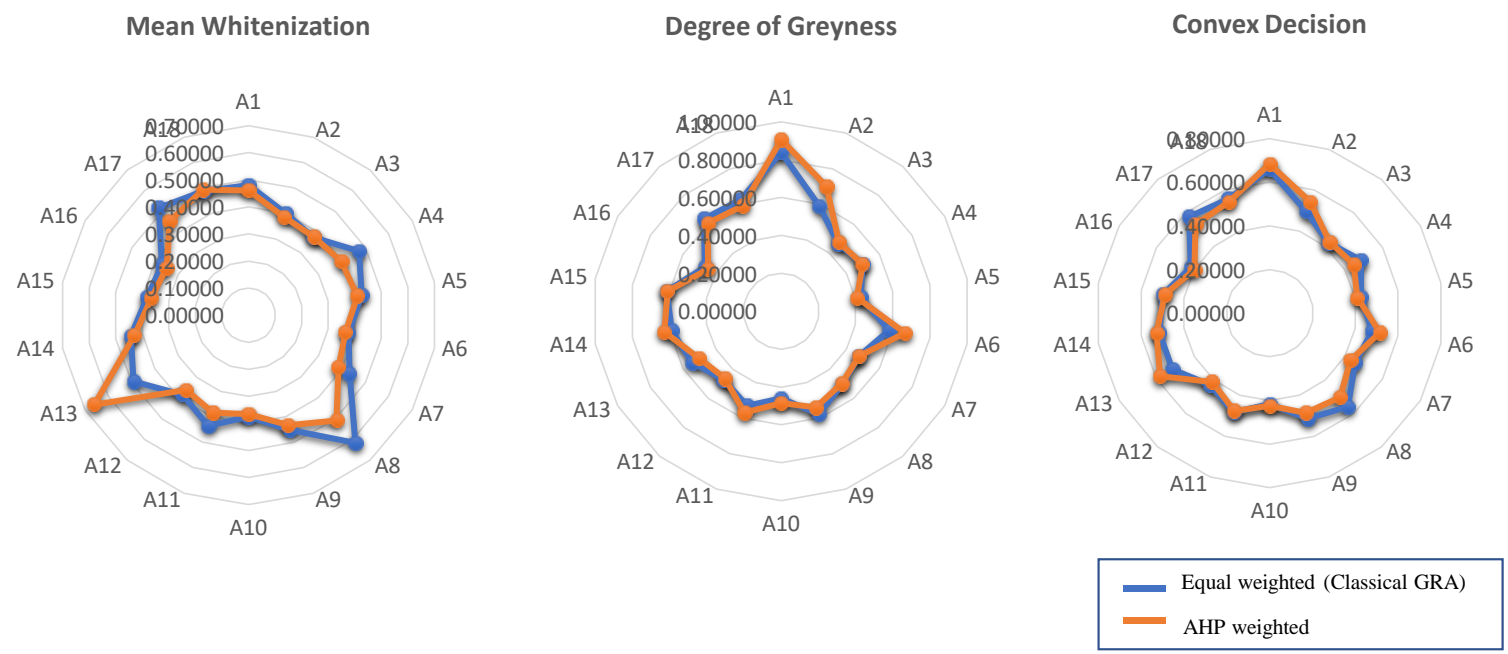

Figure 4. The changes of GRD results of study.

When all results are evaluated, as a intersection solution set, A1 - A2 - A6 - A8 - A13 - A14 - A15 A17 - A18 must be prefer for the information and technology investment portfolio in the first fifty percent for Borsa Istanbul stock exchange according to financial performance evaluation of the year 2020.

\section{CONCLUSIONS}

In the study, the performance of the information and technology sector stock indexes of BIST has been demonstrated by using AHP and GRA methods. The financial criteria are selected by using the experts' opinions and the criteria weights are determined by using experts' Opinions (Academician, Financial Manager and Investor) on AHP pairwise comparison matrices under higher consistency ratios.

In GRA, mean and degree of greyness approaches are used for whitenization to interval grey values from 4 periods in 2020. It was concluded that the best performing enterprises were at an acceptable level in terms of liquidity ratios during the periods covered by the study, the borrowing policy was used correctly, and they continued their activities profitably compared to other enterprises operating in the sector. When the profitability ratios, which are determined as the most weighted criterion, are considered, it is seen that the profitability ratios of the companies that stand out in the ranking are at higher levels compared to the other businesses, while the profitability ratios of the companies with low performance are generally not at the desired levels. Then, as well as mean weighted and degree of greyness whitenization results are obtained, a convex decision solution is applied for the average of the classical GRA and the AHP-weighted (using experts' opinions) GRA. As a result, the prioritization of the stocks for portfolio management is provided to finance researchers in the most useful financial ratios. 


\section{REFERENCES}

[1] M. Tekin and M. Zerenler, İş Dünyası Iç̧in Krizi Yönetebilmenin Sırları. Konya, Türkiye: Çizgi Kitabevi, 2005.

[2] F. A. N. Tayyar, E. Genç and I. Erem, "BİST'e Kayıtlı Bilişim ve Teknoloji alanında Faaliyet Gösteren İşletmelerin Finansal Performanslarının Analitik Hiyerarşi Prosesi (AHP) ve Gri İlişkisel Analiz (GİA) yöntemiyle değerlendirilmesi," Muhasebe ve Finansman Dergisi, c. 2014, s. 61, ss. 1940, 2014.

[3] I. Aydın, "Bilişim sektörü ve Türkiye'nin sektördeki potansiyeli," International Journal of New Trends in Arts, Sports \& Science Education, vol. 1, no. 1, pp. 180-200, 2012.

[4] C. Ceylan and U. Çağlar, Küreselleşmenin Sektörel Etkileri: Araştırma Projesi. İstanbul, Türkiye: İstanbul Ticaret Odası Yayınları Küresel Ekonomik Araştırmalar, 2011.

[5] I. Marković, M., Stojanović, J., Stanković, and M. Stanković, "Stock market trend prediction using AHP and weighted kernel LS-SVM," Soft Computing, vol. 21, no. 18, pp. 5387-5398, 2017.

[6] S. Lin and S. Ling-Wu, "Is grey relational analysis superior to the conventional techniques in predicting financial crisis?," Expert Systems with Applications, vol. 38, no. 5, pp. 5119-5124, 2011.

[7] A. Ozdemir and M. Deste, "Gri ilişkisel analiz ile çok kriterli tedarikçi seçimi: otomotiv sektöründe bir uygulama," İstanbul Üniversitesi Işsletme Fakültesi Dergisi, c. 38, s. 2, ss. 147-156, 2009.

[8] I. Peker and B. Baki, "Performance Evaluation in Turkish Insurance Sector with Grey Relationship Analysis," International Journal of Economic and Administrative Studies, vol. 3, no. 7, pp. 1-17, 2011.

[9] C. Wu, C. T. Ru-Lin and P. H. Tsai, "Evaluating business performance of wealth management banks," European Journal of Operational Research, vol. 207, no. 2, pp. 971-979, 2010.

[10] Y. Sahin and H. Akyer, "Efficient use of country resources: practice of the AHP and topsis methods in selection of 4x4 search and Rescue (Sar) vehicle," Süleyman Demirel University Visionary Journal, vol. 3, no. 5, pp. 72-87, 2011.

[11] T. Poklepović and Z. Babić, "Stock selection using a hybrid MCDM approach," Croatian Operational Research Review, vol. 5, no. 2, pp. 273-290, 2014.

[12] C. T. Tsao, "A fuzzy MCDM approach for stock selection," Journal of the Operational Research Society, vol. 57, no. 11, pp. 1341-1352, 2006.

[13] H. S. A. V. K. Hota and S. K. Singhai, "Comparative analysis of AHP and its integrated techniques applied for stock index ranking," in Progress in Intelligent Computing Techniques: Theory, Practice, and Applications, P. K. Sa, M. N. Sahoo, M. Murugappan, Y. Wu, B. Majhi Eds., Singapore, Springer, 2018, pp. 127-134.

[14] M. M. M. H. A. M. A. Momeni, J. S. Moradi and J. Mohammadi, "A fuzzy MCDM approach for evaluating listed private banks in Tehran stock exchange based on balanced scorecard," International Journal of Business Administration, vol. 2, no. 1, pp. 80-97, 2011. 
[15] E. F. E. A. Mills, M. A. Baafi, N. Amowine and K. Zeng, "A hybrid grey MCDM approach for asset allocation: evidence from China's Shanghai Stock Exchange," Journal of Business Economics and Management, vol. 21, no. 2, pp. 446-472, 2020.

[16] W. R. J. Ho, C. L. Tsai, G. H. Tzeng and S. K. Fang, "Combined DEMATEL technique with a novel MCDM model for exploring portfolio selection based on CAPM," Expert Systems with Applications, vol. 38, no. 1, pp. 16-25, 2011.

[17] R. Dash, S. Samal, R. Dash and R. Rautray, "An integrated TOPSIS crow search based classifier ensemble: In application to stock index price movement prediction," Applied Soft Computing, vol. 85, no. 105784, 2019.

[18] G. P. Y. Kou and G. Wang, "Evaluation of clustering algorithms for financial risk analysis using MCDM methods," Information Sciences, vol. 275, pp. 1-12, 2014.

[19] P. J. G. Pineda, J. J. Liou, C. C. Hsu and Y. C. Chuang, "An integrated MCDM model for improving airline operational and financial performance," Journal of Air Transport Management, vol. 68, pp. 103-117, 2018.

[20] A. Safaei Ghadikolaei, S. Khalili Esbouei and J. Antucheviciene, "Applying fuzzy MCDM for financial performance evaluation of Iranian companies," Technological and Economic Development of Economy, vol. 20, no. 2, pp. 274-291, 2014.

[21] W. S. Lee, G. H. Tzeng, J. L. Guan, K. T. Chien and J. M. Huang, "Combined MCDM techniques for exploring stock selection based on Gordon model," Expert Systems with Applications, vol. 36, no. 3, pp. 6421-6430, 2009.

[22] H. Bagci and C. Y. Kaygin, "The Financial Performance Measurement of the Companies Listed In The BIST Holding and Investment Index by the MCDM Methods," The Journal of Accounting and Finance, vol. 87, pp. 301-324, 2020.

[23] M. Baydas and O. E. Elma, "An objectıve criteria proposal for the comparison of MCDM and weighting methods in financial performance measurement: An application in Borsa Istanbul," Decision Making: Applications in Management and Engineering, vol. 4, no. 2, pp. 257-279, 2021.

[24] E. Aldalou and S. Perçin, "Application of integrated fuzzy MCDM approach for financial performance evaluation of Turkish technology sector," International Journal of Procurement Management, vol. 13, no. 1, pp. 1-23, 2020.

[25] K. H. Chen and T. A. Shimerda, "An empirical analysis of useful financial ratios," Financial management, vol. 10, no. 1 pp. 51-60, 1981.

[26] P. Barnes, "The analysis and use of financial ratios," Journal of Business Finance dan Accounting, vol. 14, no. 4, pp. 449-461, 1987.

[27] J. Lewellen, "Predicting returns with financial ratios," Journal of Financial Economics, vol. 74, no. 2 , pp. 209-235, 2004.

[28] H. Ozturk and T. A. Karabulut, "The relationship between earnings-to-price, current ratio, profit margin and return: an empirical analysis on Istanbul stock exchange," Accounting and Finance Research, vol. 7, no. 1, pp. 109-115, 2018.

[29] H. O. Sarıdogan, "Financial Performance Analysis of Firms Which are Quated in Tehnology Index in the BIST," CAKU Journal of Institute of Social Sciences, vol. 11, no. 2, pp. 22-36, 2020. 
[30] A. S. Temur, "The Effect of Covid-19 Outbreak on BIST Technology Index (XUTEK)," International Review of Economics and Management, vol. 9, no. 1, pp. 28-49, 2021.

[31] F. Zahedi, "The analytic hierarchy process - a survey of the method and its applications," Interfaces, vol. 16, no. 4, pp. 96-108, 1986.

[32] T. Saaty, "How to make a decision: the analytic hierarchy process," Interfaces, vol. 24, no. 6, pp. 19-43, 1994.

[33] T. Saaty. The Analytic Hierarchy Process, New York, USA: McGraw-Hill, 1980.

[34] M. Dagdeviren and T. Eren, "Analytical Hierarchy Process and Use of 0-1 Goal Programming Methods in Selecting Supplier Firm,” J. Fac. Eng. Arch. Gazi Univ, vol. 16, no. 2, pp. 41-52, 2001.

[35] C. Kahraman, U. Cebeci and Z. and Ulukan, "Multi-criteria supplier selection using fuzzy AHP," Logistics Information Management, vol. 16, no. 6, pp. 382-394, 2003.

[36] F. T. Chan, N. Kumar, M. K. Tiwari, H. C. Lau and K. Choy, "Global supplier selection: a fuzzy-AHP approach," International Journal of Production Research, vol. 46, no. 14, pp. 3825-3857, 2008.

[37] F. Dweiri, S. Kumar, S. A. Khan and V. Jain, "Designing an integrated AHP based decision support system for supplier selection in automotive industry," Expert Systems with Applications, vol. 62, pp. 273-283, 2016.

[38] S. H. Zyoud and D. Fuchs-Hanusch, "A bibliometric-based survey on AHP and TOPSIS techniques," Expert Systems with Applications, vol. 78, pp. 158-181, 2017.

[39] C.-M. Feng and R.-T. Wang, "Performance evaluation for airlines including the consideration of financial ratios," Journal of Air Transport Management, vol. 6, no. 3, pp. 133-142, 2000.

[40] S. Liu, Y. Yang, Y. Cao and N. Xie, "A summary on the research of GRA models," Grey Systems: Theory and Application, vol. 3, no. 1, pp. 7-15, 2013.

[41] G. Wei, "Grey relational analysis method for 2-tuple linguistic multiple attribute group decision making with incomplete weight information," Expert Systems with Applications, vol. 38, no. 5, pp. 4824-4828, 2011.

[42] E. Aydemir and Y. Sahin, "Evaluation of healthcare service quality factors using grey relational analysis in a dialysis center," Grey Systems: Theory and Application, vol. 9, no. 4, pp. 432-448, 2019.

[43] Y. Sahin and E. Aydemir, "An AHP-weighted grey relational analysis method to determine the technical characteristics' importance levels of the smartphone," Eskişehir Osmangazi University Journal of Economics and Administrative Sciences, vol. 14, no. 1, pp. 225-238, 2019.

[44] H. Wu, "A comparative study of using grey relational analysis in multiple attribute decision making problems," Quality Engineering, vol. 159, no. 2, pp. 209-217, 2002.

[45] T. Sarı, K. Baynal and O. Ergul, "Supplier selection with grey relational analysis," International Journal of Emerging Research in Management \& Technology, vol. 5, pp. 61-70, 2016.

[46] E. Aydemir, F. Bedir and G. Ozdemir, "Degree of greyness approach for an EPQ model with imperfect items in copper wire industry," Journal of Grey System, vol. 27, no. 2, pp. 13-26, 2015. 